\title{
International textbook of family medicine: The application of EURACT teaching agenda
}

\author{
Igor Švab ${ }^{1}$, Milica Katić \\ ${ }^{1}$ Department of family medicine \\ University of Ljubljana, Medical faculty \\ ${ }^{2}$ Department of family medicine, Andrija \\ Štampar School of Public Health, Medical \\ School, University of Zagreb \\ Corresponding author: \\ Igor Švab \\ University of Ljubljana \\ Medical faculty, Department of family \\ medicine, Poljanski nasip 58 \\ 1000 Ljubljana, Slovenia \\ igor.svab@mf.uni-lj.si \\ Tel.: +38614386915 \\ Fax.: +38614386910 \\ Received: 9 September 2013 \\ Accepted: 19 December 2013 \\ Copyright $(\odot 2014$ by \\ Academy of Sciences and Arts \\ of Bosnia and Herzegovina. \\ E-mail for permission to publish: \\ amabih@anubih.ba
}

\begin{abstract}
The paper describes experiences in the development of an international textbook of family medicine. The process of its development has started in Slovenia, where the Slovenian authors have written a textbook, adhering strictly to the European definition of family medicine and its core competencies. The format and the approach were also adopted by Croatian authors, who have used most of the material from the Slovenian book, but have modified some of the chapters according to the situation in the country and have added some of their own. This activity has created an opportunity for a truly international collaboration in the area of education of family medicine, with a creation of an international consortium, which would be responsible for the core content of the book and local adaptations of the book according to the specificities and needs of different countries. Conclusion. This innovative approach in the development of teaching material may be interesting for a variety of smaller countries in Europe and worldwide.
\end{abstract}

Key words: Education-materials, Textbook, Family medicine, Slovenia, Croatia.

\section{Introduction}

Students need quality teaching materials that would cover the topic they are studying. This requirement is usually achieved by writing a comprehensive textbook on a subject. In this respect, family medicine is in a specific situation. Because of the breadth of the topic, writing a comprehensive book is a big task that can be achieved only by a large group of experts. Small countries may find it difficult to find individuals with expertise on all the broad areas of family medicine and their results are either a comprehensive textbook with varied quality of chapters or a textbook that does not cover all the elements of the discipline. The third solution is to translate a textbook from a foreign language, which poses another problem: the discipline of family medicine is country-specific and all the chapters can not be adequately used in all the countries. Specificities regarding culture, social and religious values, needs 
of population, social determinants of health and differences in health care system all influence the way family medicine is practiced in every country. Family doctors and their educators need to take this into consideration.

EURACT, the European academy of teachers of family medicine, has developed a document that would enable family medicine educators to adress the area of family medicine comprehensively. The EURACT teaching agenda is a document, based on the European definition of general practice/ family medicine. The definition describes the 11 charactersitics of family medicine and lists six core competencies. One of the key characteristics of family medicine is the need of the physician to take into consideration the context in which he/she works (1). The agenda document was developed as an aid in developing teaching of family medicine (2). One of the potential applications of the document was also the development of a comprehensive textbook in family medicine.

The aim of this paper is to describe the experiences in developing that kind of a textbook in partnership of two countries with different health care systems.

\section{The Slovenian situation}

In Slovenia, the first comprehensive textbook of family medicine was written in 1992 (3). The aim of the first textbook was to define the core principles of family medicine. Its main aim was to demonstrate that the discipline of family medicine is different from the others. The textbook was very successful in this respect: it has described the main features that differentiate family medicine form other disciplines and was very successful in persuading the officials at the medical faculty in Ljubljana that family medicine has a specific contribution to education of future doctors, which resulted in the creation of a department of family medicine in 1994.
Nevertheless, the textbook itself did not cover a lot of areas that were needed in teaching future doctors. Ten years later, the second textbook was produced (4). The ambition of the editors was to show the breadth of the discipline by covering all the aspects of family medicine, from clinical to organisational and attitudinal. The result was a large book with chapters of varied quality. Even if the editors went at great length to ensure good quality of the material, it became obvious that one could not find enough experts within family medicine in a small country, that would made it possible to write a comprehensive textbook. In 2012, the decision was made to write the third textbook. For this attempt, the editors have decided to follow these principles:

1. The textbook will be organised according to the European definition of family medicine and the EURACT teaching agenda $(1,2)$. The sections of the book will correspond roughly to the core competencies of family medicine, described in the document.

2. The clinical section of the book will cover only the clinical topics where there is a specific approach by a family doctor or where clinical topics are not encountered at secondary level. We have also limited ourselves to topics where we could provide our own original research or established experts.

3. The structure of every chapter was clearly defined. Each chapter was written as an explanation of a case in practice, so that the reader would follow how the principles in the chapter reflect themselves in the particular case.

4. The textbook would be aimed specifically at undergraduate medical students. It should be easy to use and relatively inexpensive, so the students could afford it. With this in mind, a textbook of 32 chapters, organised in eight sections was developed (5). 


\section{The Croatian situation}

In Croatia, the first comprehensive textbook of family medicine was written in 1986 (6). The second edition of textbook was published in 1992 and the third in 2000 (7). The aim of the first textbook was the same as in Slovenian example, i.e. to define the core principles of family medicine. This textbook was written into two parts. The first part was focused on main principles and specifities of family medicine as well as on organisational aspects. The second part was focused on specific clinical problems which occured in family medicine. In fact there was no natural relation among these two parts and students faced with the problem of recognizing and applying principles of family medicine in clinical problems solving. The need for writing new, modern textbook of family medicine was often discussed during regular annual meetings of all four departments of family medicine from Croatia. The close cooperation with departments of family medicine from Slovenia resulted with the initiative for the development of an international textbook of family medicine.

\section{Cooperation with Croatia}

After the textbook was almost finished, the contact with Croatian potential partners was established through the Split initiative. A partnership was developed according to the following principles:

- The format of the book and the format of the chapters should be the same

- Some chapters may be simply translated, but if it is necessary, adaptations of the chapters are possible. In that case, the Croatian author and the Slovenian author are co-authors of the chapter

- New chapters may be added

- The editorial process is done by two editors: the Croatian and the Slovenian.

- All the chapters need to be reviewed by original authors in case of adaptations. For new chapters, the Slovenian editor serves as the reviewer.

Based on these principles, the Croatian text was developed. The Croatian textbook contains 42 chapters, most of them are adapted from Slovenian authors, and some are added (Table).

Table Chapters of the Slovenian and Croatian textbook

\begin{tabular}{lll}
\hline Section title & Slovenian textbook & Croatian textbook \\
\hline \multirow{3}{*}{ Introduction } & Theory of family medicine & Theory of family medicine \\
& - & Development of family medicine in Croatia \\
& - & $\begin{array}{l}\text { Position and functioning of family medicine in } \\
\text { Croatia }\end{array}$ \\
\hline & Low back pain & Low back pain \\
& Chest pain & Chest pain \\
& Aacute respiratory infections & Acute respiratory infections \\
& Urinary tract infections & Urinary tract infections \\
& Arterial hypertension & Arterial hypertension \\
Diseases, signs and & Diabetes & Diabetes \\
symptoms & Depression & Depression \\
& - & Chronic opstructive pulmonary disease \\
& - & Common skin disorders \\
& - & The most frequent anemias in family medicine \\
& Alcohol dependence & Alcohol dependence \\
& - & Drug dependence \\
& Medically unexplained sysptoms & Medically unexplained sysptoms \\
\hline
\end{tabular}


Table (continued).

\begin{tabular}{|c|c|c|}
\hline Section title & Slovenian textbook & Croatian textbook \\
\hline \multirow{3}{*}{ Practice organisation } & Practice organisation & Practice organisation \\
\hline & Health centre & Health centre \\
\hline & Patient management & Patient management \\
\hline \multirow{3}{*}{ Person-centered care } & Principles of communication & Principles of communication \\
\hline & Communication in practice & Communication in practice \\
\hline & Counselling & Counselling \\
\hline \multirow{5}{*}{$\begin{array}{l}\text { Specific problem solving } \\
\text { skills }\end{array}$} & Decision making in family medicine & Decision making in family medicine \\
\hline & Home care & Home care \\
\hline & Referrals & Referrals \\
\hline & - & Drug prescribing \\
\hline & Emergency services & Emergency services \\
\hline \multirow{7}{*}{ Comprehensive approach } & Principles of prevention & Principles of prevention \\
\hline & Preventive programmes & Preventive programmes \\
\hline & - & Total cardiovascular risk \\
\hline & Lifestyle & Lifestyle \\
\hline & - & $\begin{array}{l}\text { Primary health care of preschool children in } \\
\text { family medicine }\end{array}$ \\
\hline & Multimorbidity & Multimorbidity \\
\hline & Palliative care and dying & Palliative care and dying \\
\hline \multirow{5}{*}{ Community orientation } & Health policy & Health policy \\
\hline & Family & Family \\
\hline & Family violence & Family violence \\
\hline & Medical anthropology in family medicine & Medical anthropology in family medicine \\
\hline & - & $\begin{array}{l}\text { Specifities of family medicine in rural areas and } \\
\text { islands }\end{array}$ \\
\hline \multirow{3}{*}{ Quality } & Evidence based medicine & Evidence based medicine \\
\hline & Quality assurance & Quality assurance \\
\hline & Professionalism and excellence & Professionalism and excellence \\
\hline
\end{tabular}

\section{Discussion}

The strengths of this innovative approach are in the fact that we were able to develop a model how the European definition and the EURACT teaching agenda can be applied on an example of a textbook of family medicine and to preserve its flexibility.

The potential opportunities of this activity are exciting. Based on the experience we have had with this activity, we have developed a framework that would enable other countries to join. The challenge of translating the core documents into English and offer it to the world community of educators in family medicine is an especially exciting one. The outlines of the framework are as follows:
1. The textbook will be managed by an international consortium of editors. There will be one editor per country. The editors of the project will be the persons who have already implemented the textbook in their own countries

2. The "core version" of the textbook will be written in English in order to ensure easy collaboration between different coutries regardless the native language. The "core version " will include chapters that the editors decide are of adequate quality and are co-authored by at least two authors from different countries.

3. When a country is willing to join the project, its representative will have to sign a written agreement with the consortium, which will stipulate the technical, finan- 
cial and academic consequences of this collaboration. The country will then decide which chapters of the textbook will be used and which not. The decision of new chapters will be done in collaboration with the editors of the international textbook. All the modified chapters and the new chapters will be translated to English and the editors will decide which of them warrant to become part of the international textbook.

The future of the project depends largely on the possibility to have other partners that would be able to join this activity. The coordination of different countries will certainly become a challenge if the partnership grows.

There were many challenges in the process, mainly relating to the coordination of the editorial process, translations and technical problems. Understanding the differences in health care systems and procedures in different countries was a challenge in itself. Nevertheless, the agreement is that the positive results of the cooperation far outnumber the potential problems due to the coordination of services. It is much easier to work according to the pre-determined structure and to adapt the already existing text than to rewrite the new chapter from the beginning.

\section{Conclusion}

This exciting activity is to our knowledge the only approach of that kind in the area of medical textbooks. It has a potential to become an example of international academic collaboration in the field of family medicine. It is also the first product of the Split initiative, a project that has started two years ago in Croatia. Informal contacts with representatives of other countries make us believe that this is just a start of the process of international cooperation in the area of education of family medicine in Europe.

Authors' contributions: Conception and design: IŠ; Acquisition, analysis and interpretation of data: IŠ, MK; Drafting the article: IŠ, MK; Revising it critically for important intellectual content: IŠ, MK.

Conflict of interest: The authors declare that they have no conflict of interest.

\section{References}

1. Allen J, Gay B, Crebolder HFJM, Heyrman J. Švab I, Ram P. The European definition of general practice/family medicine. London: Wonca Europe; 2002.

2. Heyrman J. The Educational agenda of general practice/family medicine. Leuven: EURACT; 2004.

3. Voljč B, Košir T, Švab I, Urlep F. General practice. Principles and techniques [In Slovenian]. Ljubljana: Sekcija splošne medicine Zveze zdravniških društev - SZD; 1992.

4. Švab I, Rotar Pavlič D. Family medicine [In Slovenian]. Ljubljana: Združenje zdravnikov splošne/ družinske medicine SZD; 2002.

5. Švab I, Rotar Pavlič D. Family medicine [In Slovenian]. Ljubljana: Združenje zdravnikov družinske medicine; 2012.

6. Budak A. Family medicine (Textbook for students and manual for doctors) [In Croatian]. Zagreb: Školska knjiga; 1986.

7. Budak A. Family medicine (Textbook for students and manual for doctors) Third amended and changed edition [In Croatian]. Zagreb: Gandalf; 2000 . 